Research Paper

\title{
In vitro activity of Amazon plant extracts against Enterococcus faecalis
}

\author{
Adriana Lígia de Castilho ${ }^{1}$, Juliana Paola Correa da Silva ${ }^{1}$, \\ Cintia Helena Coury Saraceni ${ }^{1}$, Ingrit Elida Collantes Díaz ${ }^{2}$, \\ Mateus Luís Barradas Paciencia ${ }^{2}$, Antonio Drauzio Varella ${ }^{2}$, Ivana Barbosa Suffredini ${ }^{1,2}$ \\ ${ }^{1}$ Programa de Graduação em Odontologia, Universidade Paulista, São Paulo, SP, Brazil. \\ ${ }^{2}$ Laboratório de Extração, Núcleo de Pesquisas em Biodiversidade, São Paulo, SP, Brazil.
}

Submitted: November 2, 2012; Approved: March 14, 2014

\begin{abstract}
Previous studies analyzing 2,200 plant extracts indicated anti-enterococcal activity in 25 extracts obtained from Brazilian forests' plants. In the present study, these extracts were subjected to microdilution broth assay (MDBA) and disk diffusion assay (DDA) using planktonic Enterococcus faecalis $\mathrm{ATCC}^{\mathbb{B}} 29212^{\mathrm{TM}}$ and were submitted to phytochemical analysis in TLC and HPLC. Three extracts obtained from Ipomoea alba (MIC $<40 \mu \mathrm{g} / \mathrm{mL}$ ), Diclinanona calycina (MIC $\leq 40 \mu \mathrm{g} / \mathrm{mL}$ ) and Moronobea coccinea $(40<\mathrm{MIC}<80 \mu \mathrm{g} / \mathrm{mL} ; \mathrm{MBC}=80 \mu \mathrm{g} / \mathrm{mL})$ showed significant bactericidal activity in the MDBA and four extracts obtained from $I$. alba (14.04 $\pm 0.55 \mathrm{~mm}$ diameter) $S$. globulifera ( $14.43 \pm 0.33 \mathrm{~mm}$ and $12.18 \pm 0.28 \mathrm{~mm}$ diameter) and Connarus ruber var. ruber $(13.13$ $\pm 0.18 \mathrm{~mm}$ diameter) were active in DDA. Residues $\mathrm{H}_{2} \mathrm{O}$ obtained from Psidium densicomum (mean of $16.78 \mathrm{~mm}$ diameter) and from Stryphnodendron pulcherrimum (mean of $15.97 \mathrm{~mm}$ diameter) have shown an improved antibacterial activity after fractionation if compared to that obtained from the respective crude extracts. Antioxidant activity was observed in some residues of the active extracts. TLC analysis showed that phenolic compounds are likely to be found in active extracts. Three molecules were isolated from $S$. globulifera and were identified by ${ }^{13} \mathrm{C}$ NMR lupeol, $\alpha$-amyrin and $3 \beta$-hydroxyglutin-5-ene. The present chemical and biological findings suggest that these extracts are a potential source of new anti-Enterococcus compounds to be introduced in endodontic therapy.
\end{abstract}

Key words: Enterococcus faecalis, endodontitis, antibacterial activity, Amazon rain forest, bioprospection.

\section{Introduction}

Enterococcus faecalis is one of the main nosocomial pathogens (Horner et al., 2005) which may be resistant to a wide range of antimicrobial agents, causing several diseases. These bacteria inhabit the gastrointestinal and genitourinary tracts and have been related to infectious endocarditis and surgical wound infection (Pasticci et al., 2008). In the oral cavity, E. faecalis is likely to be found in caries lesions, in periodontal diseases (Souto et al., 2006), and mainly in endodontic infections (Hancock et al., 2001, Duggan and Sedgley, 2007), in which pulp may become infected via dentinal tubules, through carious lesions, and via periodontal disease. Studies have shown that remaining $E$. faecalis contributes to the failure of endodontic therapy. The suppression and control of E. faecalis in dental procedures is paramount to diminish invasion of bacteria in dentinal tubules (Love, 2001), as well as to avoid strains to get resistance to several antibiotics (Aslangul et al., 2005) and irrigating solutions, to avoid bacteria adaptation to environments where nutrients are scarce, and to abolish the establishment of any relationship with other bacteria, as in biofilms, environment and virulence factors (Kayaoglu and Orstavik, 2004).

Chemical and mechanical site preparation in the treatment of caries lesions and periodontal and endodontic infections aim to reduce infection and provide a favorable

Send correspondence to I.B. Suffredini. Centre for Research in Biodiversity, Extraction Laboratory, Paulista University; Av. Paulista 900, 1 andar, Bela Vista, 01310-100 São Paulo, SP, Brazil. E-mail: ibsuffredini@yahoo.com.br. 
environment for an effective treatment. Chemical preparation in endodontics is synonym of sodium hypochloride (SH). Currently, there is a limited number of irrigating substances with antimicrobial properties that can be used in periodontal and endodontic treatment, as well as in the treatment of carious lesions. Most of the chemical substances show adverse factors, such as toxicity, non-physiological $\mathrm{pH}$, unpleasant odor and taste, and inability to degrade organic matter and smear layer. One of the most widely indicated substance is SH diluted to $1 \%$ (Estrela et al., 2008).

The use of SH as irrigation solution is part of the protocols established to prepare root canals to endodontic treatments, considering that removal of any microorganism is fundamental to avoid any further relapse. One of the main microorganisms found in recurrent failure in endodontic treatment is E. faecalis, which is a bacterium that exhibits increased virulence in pathological conditions of endodontic disease. For that reason, this bacterium is one of the main target for drug action in the treatment of this oral pathological condition (Pinheiro et al., 2004; Pinheiro et al., 2003). Considering the undesirable effects related to $\mathrm{SH}$, it has become increasingly necessary to find new tools to assist in the fight against $E$. faecalis.

Systematic studies with plant and animal extracts (Alviano et al., 2008) have shown that it is possible to find compounds with pharmaceutical potential, such as some antibacterial chemotherapeutic agents (penicillin, erythromycin, tetracyclin). Universidade Paulista (UNIP), Brazil, introduced in 1996 a large-scale bioprospecting program targeting the identification of antibacterial compounds in plant extracts native to Brazilian forests. Throughout the program, over 2,000 plant extracts were tested against several microorganisms, such as Staphylococcus aureus, Escherichia coli, Pseudomonas aeruginosa, Candida albicans, Streptococcus mutans, S. sanguinis, and Enterococcus faecalis (Suffredini et al., 2006a; Suffredini et al., 2006b; Suffredini et al., 2004; Suffredini et al., 2002). Based on these results, the present study aimed the study of the antibacterial activity of 25 plant extracts and their residues against traditional antibacterial assays and to search for chemical groups that may occur in the active extracts and residues, emphasizing an organic extract obtained from Symphonia globulifera, which was available in higher amounts to develop initial chemical studies.

\section{Material and Methods}

\section{Plant collection and extraction preparation}

For plant collection and extraction, our team obtained a collecting permit issued by the Brazilian Institute of Environment and Renewable Natural Resources - IBAMA and a permit to access genetic resources issued by the Genetic Heritage Management Council - CGen of the Brazilian Ministry of the Environment. Collected plants were taxo- nomically identified and voucher specimens were deposited at UNIP Herbarium, São Paulo, Brazil. Organic and aqueous extracts were obtained by a 24-h maceration with dichloromethane: methanol (1:1), followed by a 24-h maceration with distilled water (Millipore ${ }^{\circledR}$, Bedford, MA, USA) (Younes et al., 2007; Younes et al., 2000).

\section{Test compounds and controls}

Twenty-five previously selected extracts, here designed as EB 55, EB 321, EB 352, EB 429, EB 841, EB 1247, EB 1257, EB 1259, EB 1298, EB 1373, EB 1389, EB 1395, EB 1461, EB 1493, EB 1497, EB 1525, EB 1543, EB 1549, EB 1637, EB 1743, EB 1765, EB 1905, EB 1923, EB 1991 and EB 1999, which taxonomical and collection data are listed in table 1, were diluted to a series of dilutions that led to final test concentrations in the microdilution broth assay of $12,500,10,000,7,500,5,000,2,500,1,300,600,310$, 160,80 , and $40 \mu \mathrm{g} / \mathrm{mL}$, being 20 times more diluted than the initial extracts dilutions, according to the established protocol). Dimethylsulfoxide and water were used as solvent in the dilution procedure. Sodium hypochlorite $1 \%$ (SH) was used as positive control, and was obtained from a formulated SH 10\% solution (Fórmula \& Ação - Compounding Pharmacy). A $1 \%$ SH commercial solution (Asfer ${ }^{\mathbb{R}}$, São Paulo, SP, Brazil) was also used as positive control. The same extracts were tested in disk diffusion assay at a concentration of $200 \mathrm{mg} / \mathrm{mL}$, diluted in dimethylsulfoxide $50 \%$ in water. All organic extracts were diluted in dimethylsulfoxide 50\% (DMSO50).

\section{Enteroroccus faecalis}

The biosafety level 2 bacteria used in all assays were obtained from ATCC. Bacteria was acquired lyophilized, in Loops ${ }^{\circledR}$ (Oxoid Ltd, London, England), and was seeded in Müeller-Hinton agar (Oxoid Ltd, London, England), put in an incubator for $24 \mathrm{~h}$, at $36^{\circ} \mathrm{C}$. this plate was called "mother-plate", and was left to be used within 30 days, if kept under refrigeration. 24-h fresh colonies were acquired before each assay, so, bacteria were at the same $4^{\text {th }}$ passage during every experiment performed in the present work.

\section{Disk diffusion assay and the determination of the growth inhibition zone diameter}

Disk diffusion assay was done as usually described for plant extracts analysis (Souto et al., 2006), in strict sterile conditions. A $0.5 \mathrm{McF}$ arland saline suspension was prepared from a fresh colony of Enterococcus faecalis ATCC $^{\circledR}$ $29212^{\mathrm{TM}}$. Assay was performed in sterile Müeller-Hinton agar prepared in Petri dishes. Sterile swabs were used to seed bacteria on the medium surface. Six paper disks measuring $6 \mathrm{~mm}$ diameter were distributed over inoculated medium surface. Then, $10 \mu \mathrm{L}$ of extracts and residues were added to each disk, in triplicate. Dishes were incubated at $36{ }^{\circ} \mathrm{C}$ for $24 \mathrm{~h}$. After that, the diameters of growth inhibi- 


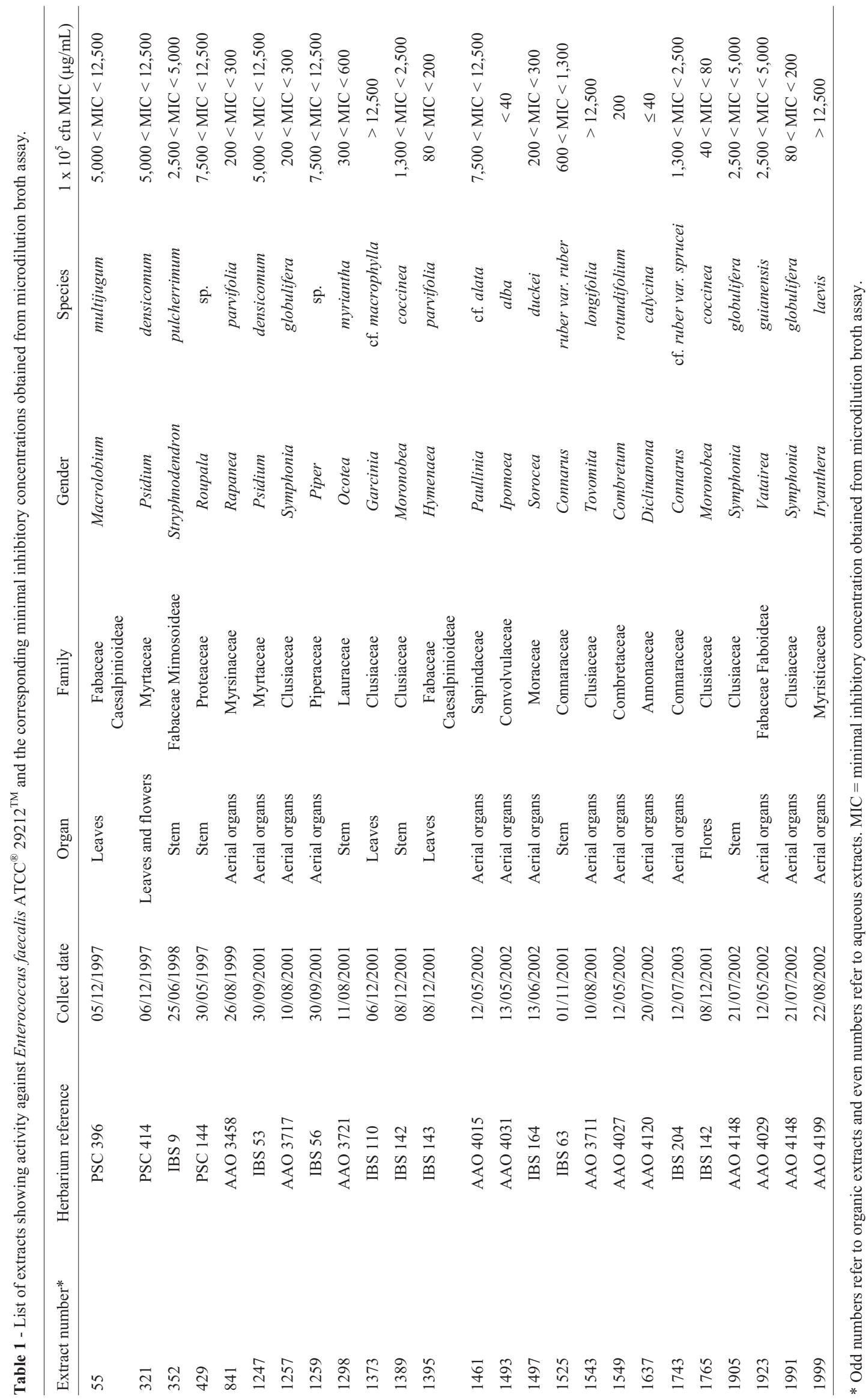


tion zones were measured horizontally and vertically with a caliper rule.

\section{Statistical analysis for disk diffusion assays}

One-way ANOVA and Tukey's post-test analysis was applied in the evaluation of growth inhibition zone diameters resulted from the antibacterial activity of plant extracts and their residues, $\mathrm{SH} 1 \% \mathrm{~F}=$ formulated sodium hypochlorite $1 \%$; $\mathrm{SH} 1 \% \mathrm{C}=$ commercial sodium hypochlorite $1 \%$ (standard drugs used as positive control), against Enterococcus faecalis $\mathrm{ATCC}^{\circledR} 29212^{\mathrm{TM}}$. Results were significant if $\mathrm{p}<0.05$.

\section{Microdilution broth assay and determination of minimal inhibitory concentration and minimal bactericidal concentration}

The extracts were tested by the microdilution broth assay (MDBA), in completely sterile conditions, adapted to high-throughput conditions (Suffredini et al., 2006b), in a biosafety level 2 Laboratory Unit, using sterilized Müeller-Hinton broth medium (Oxoid Ltd, London, England), in 96-well microplates, with inocula adjusted to a $0.5 \mathrm{McF}$ arland standard, or $1 \times 10^{8}$ colony-forming unit per $\mathrm{mL} \quad(\mathrm{cfu} / \mathrm{mL})$, obtained from fresh colonies of Enterococcus faecalis $\mathrm{ATCC}^{\circledR} 29212^{\mathrm{TM}}$ (Suffredini et al., 2006a; Suffredini et al., 2006b; Suffredini et al., 2004) grown on sterilized Müeller-Hinton agar medium (Oxoid Ltd, London, England). Concentrations of bacterial suspension, such as $1 \times 10^{2}, 1 \times 10^{3}, 1 \times 10^{4}, 1 \times 10^{5}, 1 \times 10^{6}$, and $1 \times 10^{7} \mathrm{cfu} / \mathrm{mL}$, were prepared in sterilized Müeller -Hinton broth medium (Oxoid Ltd, London, England) starting from the $1 \times 10^{8}$ colony-forming unit per $\mathrm{mL}$ (cfu/mL) suspension. Thus, a 190- $\mu \mathrm{L}$ aliquot of the inoculum was dispensed into the wells, and $10 \mu \mathrm{L}$ aliquots of extract, residue or standard compound solutions were then added to the inoculum. Microplates were incubated at $37^{\circ} \mathrm{C}$ for $24 \mathrm{~h}$. Inhibition of bacterial growth was assessed visually, and bacterial suspensions from all test wells were subcultured in sterile agar medium in order to evaluate bactericidal activity.

Following a procedure similar to that described above in sterile MDBA, minimal inhibitory concentration (MIC) and minimal bactericidal concentration $(\mathrm{MBC})$ were obtained for the 25 plant extracts (PE), against E. faecalis. Solvent dimethylsulfoxide were tested as negative control.

\section{Liquid-liquid partition and biological assay of residues}

Each one of the 25 extracts was partitioned with three solvents of different polarities resulting in non polar residues (chloroform residue, or Residue $\mathrm{CHCl}_{3}$, or $\mathrm{EB}-\mathrm{CHCl}_{3}$ where EB refers to the extract number), intermediate-polarity residues (butanol residue, or Residue $\mathrm{BuOH}$, or EB$\mathrm{BuOH}$ where $\mathrm{EB}$ refers to the extract number), and polar residues (aqueous residue, or Residue $\mathrm{H}_{2} \mathrm{O}$, or $\mathrm{EB}-\mathrm{H}_{2} \mathrm{O}$ where $\mathrm{EB}$ refers to the extract number). The solvents were completely evaporated, followed by lyophilization, resulting in 75 residues. Organic solvents were completely removed under vacuum. All residues were re-suspended in $50 \%$ dimethylsulfoxide (DMSO50) or in distilled water (both tested as negative controls), at the concentration of $200 \mathrm{mg} / \mathrm{mL}$, to be tested, as follows.

For preparation of $200 \mathrm{mg} / \mathrm{mL}$ solutions, aqueous residues were diluted with Milli-Q distilled water (Millipore ${ }^{\circledR}$, Bedford, MA, USA) and chloroform and butanol residues were diluted in DMSO50, in order to be assayed by the MDBA, according to the technique previously described, in bacterial suspensions containing $1 \times 10^{6} \mathrm{cfu} / \mathrm{mL}$.

\section{Thin-layer chromatography}

Thin-layer chromatography (TLC) was performed with extracts and residues. Silica gel GF chromatography sheets (Merck ${ }^{\circledR}$, Whitehouse Station, New Jersey, USA) were used and the following mobile phase were prepared: System 1 - hexane and ethyl acetate (4:1) applied on chromatographic sheet 1; System 2 - chloroform and ethyl acetate $(1: 1)$ applied on chromatographic sheet 2; and System 3 - chloroform, ethyl acetate and methanol (2:2:1); System 4 - ethyl acetate, methanol and water (100:13.5:10); System 5 - ethyl acetate, glacial acetic acid, formic acid and water (100:11:11:26). Revelation of spots was done with potassium hydroxide (A); Kedde Reagent (B), Dragendorff Reagent (C), NP Reagent (D), 25\% sulfuric acid solution (E) and $\beta$-caroten (F). Ultraviolet light at 254 and/or $366 \mathrm{~nm}$ (uv254 or uv356) was used to develop some of the chromatograms (Suffredini et al., 2004).

\section{Evaluation of antioxidant potential}

Evaluation of the antioxidant potential of extracts and residues was performed using the $\beta$-carotene technique (Pratt and Miller, 1984), in System 3 described above. A mixture of two solutions composed of (a) 9-mg $\beta$-carotene dissolved in $30 \mathrm{~mL}$ of chloroform and (b) two drops of linoleic acid dissolved in $60 \mathrm{~mL}$ of ethanol was used to reveal antioxidant substances in chromatogram. The chromatograms were exposed to natural light for at least $2 \mathrm{~h}$ in order to catalyze the antioxidant reaction between the natural product and the development system.

\section{Fractionation of EB 1257}

Extract EB1257, obtained from the aerial organs of $S$. globulifera, was used in the chemical assays.

\section{Column chromatography fractionation}

In order to isolate major compounds, $16.7668 \mathrm{~g}$ of extract 1257 were submitted to liquid-liquid partition using the technique first described, which resulted in Residue $\mathrm{CHCl}_{3}$ (7212.6 mg, or $43.02 \%$ yield) Residue $\mathrm{BuOH}$ (3815.3 $\mathrm{mg}$, or $22.76 \%$ yield) and Residue $\mathrm{H}_{2} \mathrm{O}$ ( $5738.9 \mathrm{mg}$, or $34.23 \%$ yield). Residue $\mathrm{CHCl}_{3}$ was submitted to open CC fractionation with Sephadex LH-20 as sta- 
tionary phase, and $100 \%$ hexane, $100 \%$ dichloromethane and $100 \%$ methanol, as mobile phase, and resulted in hexane fraction (3031.2 $\mathrm{mg}$, or $42.03 \%$ yield), dichloromethane fraction (1230.9, or $17.07 \%$ yield $\mathrm{mg}$ ) and methanol fraction ( $2950.5 \mathrm{mg}$, or $40.91 \%$ yield).

Chromatographic techniques used in the isolation of major compounds - thin layer chromatography and normal phase open column chromatography

The hexane fraction obtained from Residue $\mathrm{CHCl}_{3}$, which was obtained from EB1257, was submitted to fractionation in column chromatography using silica gel 60-200 $\mu \mathrm{m}$ as stationary phase and a gradient with increasing polarity composed by mixtures of hexane, ethyl acetate and methanol as mobile phase, which resulted in 28 fractions. The fractions were compared by TLC and were grouped according to their similarity, after analysis with sulfuric acid $25 \%$ and heating, resulting in fractions 10-11, 12, 13, 14-15, 16, 17,.., 28. Fraction 13, named UNIP147 was sent to ${ }^{1} \mathrm{H}$ NMR and e ${ }^{13} \mathrm{C}$ NMR, in $\mathrm{CDCl}_{3}$.

Fraction 13 (or UNIP147) was obtained as a crystal cream sample $(30 \mathrm{mg}) .{ }^{1} \mathrm{H}$ NMR was obtained but it showed to be complex. So, a ${ }^{13} \mathrm{C}$ NMR was obtained in order to support molecules' identification. Three molecules were identified and their spectra were compared to that in the literature.

\section{Results}

Taxonomic information of the 25 plants included in the present study is provided in Table 1 and extracts are referred to in the text by their extract number.

Figure 1 represents the comparison among means obtained from inhibition growth zone diameters of the extracts and positive / negative controls, in the disk diffusion assay against $0.5 \mathrm{McF}$ arland inoculum of $E$. faecalis. One- way ANOVA followed by Tukey's post-test indicated that the means were significant different $\left(\mathrm{F}_{(26,135)}=32.06\right.$; $\mathrm{p}<0.0001 ; R^{2}=0.8606,27$ groups). Results generated from both DMSO solutions (media $=0.00 \mathrm{~mm}$ growth inhibition zone diameters) were not included in statistical analysis due to the lack of homocedasticity if those groups were included. The following treatments showed to be as efficient as $\mathrm{SH} 1 \% \mathrm{~F}(\mathrm{p}>0.05)$ : 55.PE, 352.PE, 841.PE, 1247.PE, 1257.PE, 1298.PE, 1373.PE, 1389.PE, 1497.PE, 1549.PE, 1743.PE, 1765.PE, 1905.PE, 1923.PE, 1999.PE. The following treatments showed to be significantly more efficient than SH1\%F ( $<0.05)$ : 1493.PE, 1525.PE and 1991.PE. Considering SH1\%C, the following treatments showed equivalent antibacterial activity $(\mathrm{p}>0.05)$ : 1257.PE, 1298.PE, 1389.PE, 1497.PE, 1525.PE and 1999.PE.Lastly, the following treatments were significantly more efficient than SH1\%C ( $<<0.05)$ : 1493.PE 1991.PE.

Figure 2 represents the comparison among means obtained from inhibition growth zone diameters of the extracts, residues and standard drugs, in the disk diffusion assay against $0.5 \mathrm{McF}$ arland inoculum of $E$. faecalis using one-way ANOVA followed by Tukey's post-test. Results generated from both DMSO solutions (mean $=0.00 \mathrm{~mm}$ growth inhibition zone diameters) were not included in statistical analysis due to the lack of homocedasticity if those groups were included. The following treatments showed to be as efficient as $\mathrm{SH} 1 \% \mathrm{~F}(\mathrm{p}>0.05): 55 . \mathrm{BuOH}, 321 . \mathrm{BuOH}$, 352.BuOH, 1257. $\mathrm{CHCl}_{3}, 1257 . \mathrm{Aq}, 1389 . \mathrm{Aq}, 1525 . \mathrm{Aq}$ and 1991. $\mathrm{CHCl}_{3}$. The following treatments were more effective than SH1\%F (p < 0.05): 321.Aq, 352.Aq, 841.BuOH, 1257. BuOH, 1259.BuOH, 1298. BuOH, 1389. BuOH, 1493. $\mathrm{CHCl}_{3}, 1493 . \mathrm{BuOH}, 1525 . \mathrm{BuOH}$ and 1991.BuOH. In relation to $\mathrm{SH} 1 \% \mathrm{C}$, the following treatments were statistically equivalent antibacterial activity $(\mathrm{p}>0.05)$ :

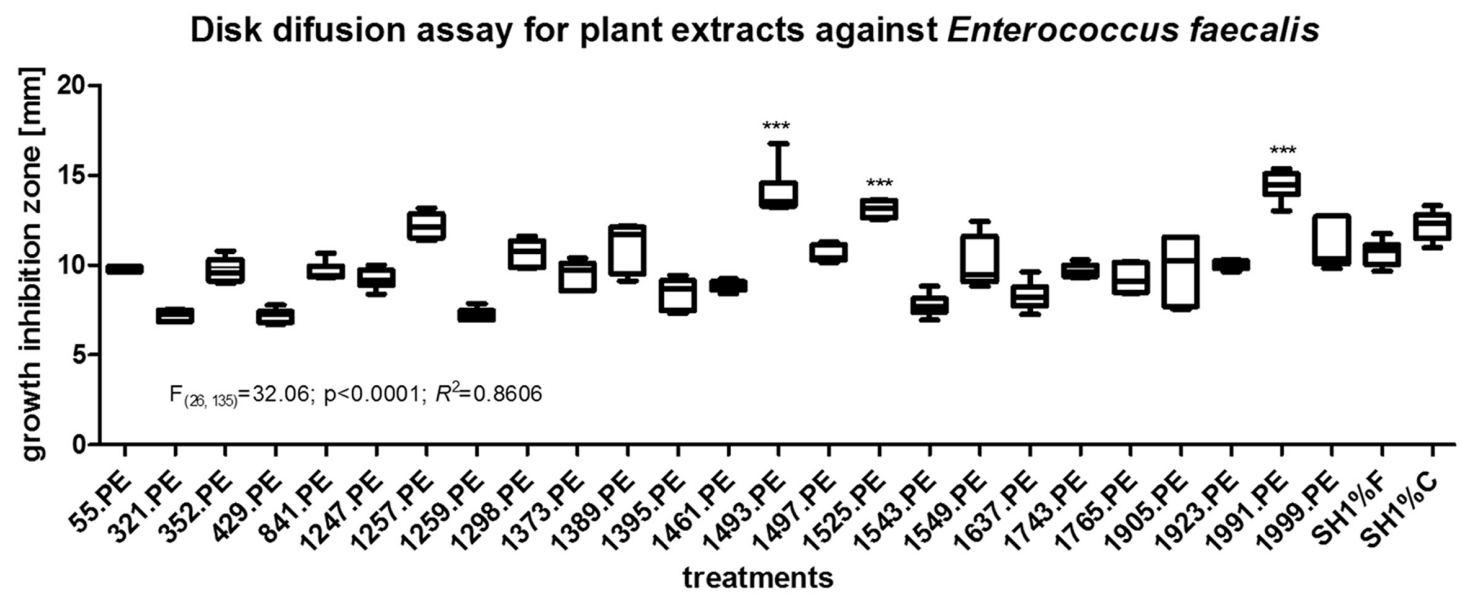

Figure 1 - Two-way ANOVA and Bonferroni's post-test analysis related to growth inhibition zone diameters obtained from the antibacterial activity in disk diffusion assay of plant extracts and their chloroform, buthanol and aqueous residues (concentration of $200 \mathrm{mg} / \mathrm{mL}$ ), formulated and commercial sodium hypochloride $1 \%$ (used as positive controls) and dimethylsulfoxide $50 \%$ and pure (used as negative control), against Enterococcus faecalis ATCC ${ }^{\circledR}$ $29212^{\mathrm{TM}}$. SH1\%F = formulated sodium hypochlorite $1 \%$; SH1\%C = commercial sodium hypochlorite $1 \%$. Residues are nominated as XX.CHCL3, XX.BuOH, XX.H2O and XX.PE, where XX corresponds to the extract number. Significance were considered if $\mathrm{p}<0.05$. 
Disk diffusion assay with extracts and their residues against Enterococcus faecalis
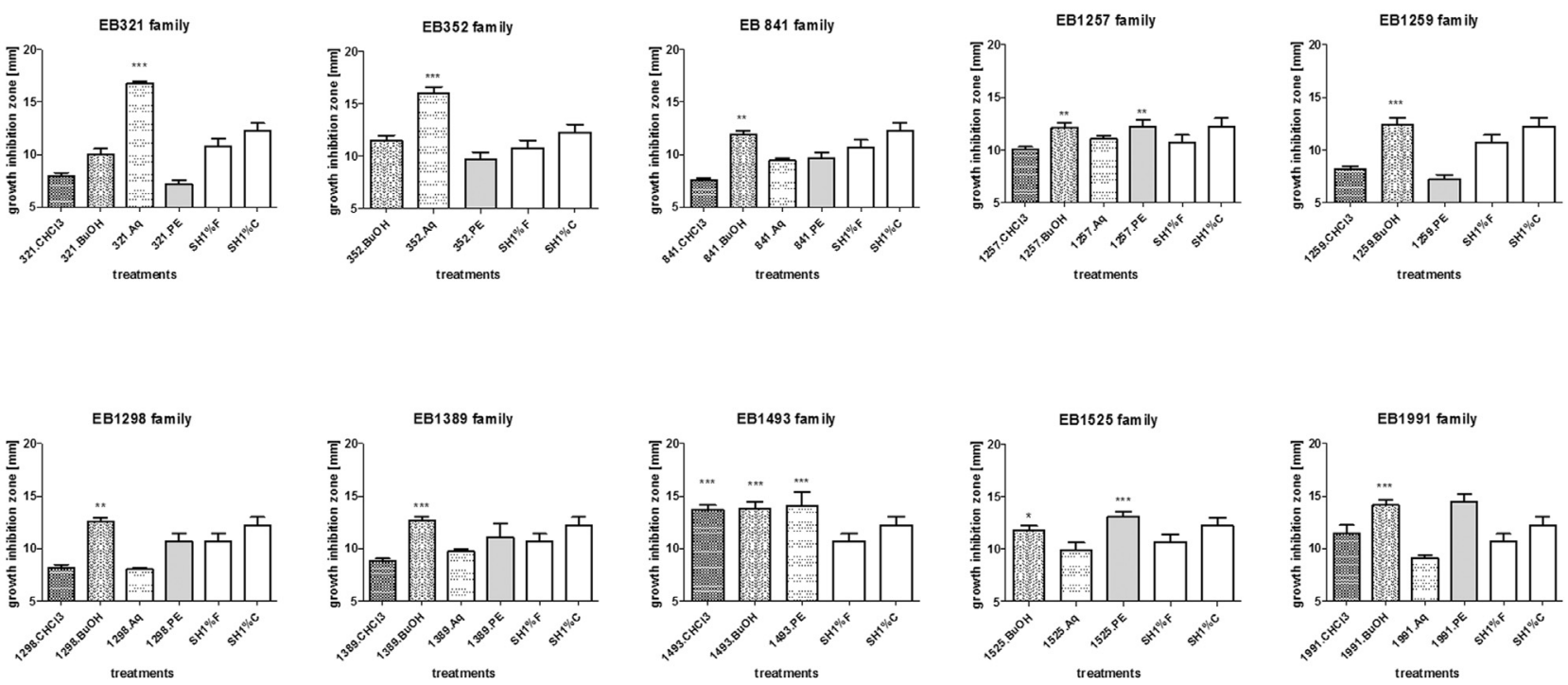

Figure 2 - One-way ANOVA and Tukey's post-test analysis related to growth inhibition zone diameters obtained from the antibacterial activity in disk diffusion assay of plant extracts, residues (concentration of $200 \mathrm{mg} / \mathrm{mL}$ ), formulated and commercial sodium hypochloride $1 \%$ (used as positive controls), against Enterococcus faecalis $\mathrm{ATCC}^{\circledR} 29212^{\mathrm{TM}}$. SH1\%F = formulated sodium hypochlorite $1 \%$; SH1\%C = commercial sodium hypochlorite $1 \%$. Significance were considered if $\mathrm{p}<0.05$.

55. $\mathrm{BuOH}, \quad 352 . \mathrm{BuOH}, \quad 841 . \mathrm{BuOH}, \quad$ 1257. $\mathrm{BuOH}$, 1259. BuOH, 1298. BuOH, 1389. BuOH, 1525.BuOH and 1991. $\mathrm{CHCl}_{3}$. Finally, the following treatments were more effective than SH1\%C (p<0.05): 321.Aq, 352.Aq, 1493. $\mathrm{CHCl}_{3}, 1493 . \mathrm{BuOH}$ and 1991.BuOH.

Table 2 shows the antioxidant activity of residues. Antioxidant compounds are prone to be found in residues $\mathrm{BuOH}$ obtained from extracts EB 55, EB 841, EB 1257, EB 1373, EB 1389, EB 1525, EB 1905, EB 1991 and EB 1999. Also, antioxidant compounds are prone to be found in residues $\mathrm{CHCl}_{3}$ obtained from extract $\mathrm{EB} 1637$ and in residues $\mathrm{H}_{2} \mathrm{O}$ obtained from extracts EB 1525 and EB 1905.

TLC analysis of EB 321, EB 352, EB 1257, EB 1493, EB 1525, EB 1765, EB 1991 and EB 321 indicated that phenolic compounds might be present, once a weak blue fluorescence could be seen after NP and uv356 development. Triterpenes or essential oils (due to sulfuric acid development) may be present in EB 321. EB 352 may also have phenolic compounds (due to the yellow spots that could be seen after NP and uv356 development) and triterpenes or essential oils. EB 1257 may have coumarins or anthrone-like compounds, once the development with $\mathrm{KOH}$ showed a brown spot under visible light, and may have phenolic compounds related to orange spots observed after NP and uv 356 development. Triterpenes may also be present in this extract. EB1493 may have triterpenes as major compounds, once only the sulfuric acid solution revealed the the chromatogram. EB 1525 may have coumarins and triterpenes. EB 1765 may have antrone-like compounds (development under $\mathrm{KOH}$ and visible light), a brown spot was observed after development with Dragendorff's Reagent and NP followed by uv356 observation showed two orange and one yellow-green spots, suggesting the presence of phenolic compounds. Lastly, EB 1991 showed a yellow spot after development with $\mathrm{KOH}$, suggesting anthrone-like compounds, 3 orange and 1 yellow-green spot, after development with NP and uv356.

EB 1257 was fractionated and compounds lupeol, $\beta$-amyrin and $3 \beta$-hydroxyglutin-5-ene were isolated (Figure 3) and their structure was identified by ${ }^{13} \mathrm{C} N \mathrm{NMR}$ $\left(125 \mathrm{MHz}, \mathrm{CDCl}_{3}\right.$ ) analysis and comparison with literature (Table 3).

\section{Discussion}

E. faecalis is an important pathogen related to diseases that affect the oral cavity. In endodontic infections, especially in recurrent infection, its presence is commonly associated with treatment failure (Kayaoglu et al., 2011; Cowan, 1999). SH is a compound of choice in Dentistry, and is widely used in different concentrations, in Endodontics. Nonetheless, the compound has undesirable effects, which are often disregarded when these substances are elected because of their antimicrobial therapeutic benefit. Therefore, substances that have similar therapeutic efficacy and fewer side effects should be tracked and used in dental therapy. Natural products, such as propolis (Kayaoglu et al., 2011), are being investigated for their antibacterial activity.

Two experimental models were selected to evaluate the potential antimicrobial activity of plant extracts against 
Table 2 - Results corresponding to the antioxidant activity of residues, which represent reaction to $\beta$-caroten.

\begin{tabular}{|c|c|c|c|c|c|c|c|}
\hline Extract number & $\mathrm{CHCl}_{3}$ & $\mathrm{BuOH}$ & $\mathrm{H}_{2} \mathrm{O}$ & Extract number & $\mathrm{CHCl}_{3}$ & $\mathrm{BuOH}$ & $\mathrm{H}_{2} \mathrm{O}$ \\
\hline 55 & - & $\mathrm{X}$ & - & 1493 & - & - & - \\
\hline 321 & - & - & - & 1497 & - & - & - \\
\hline 352 & - & - & - & 1525 & - & $\mathrm{X}$ & $\mathrm{X}$ \\
\hline 429 & - & - & - & 1543 & - & - & - \\
\hline 841 & - & $\mathrm{X}$ & - & 1549 & - & - & - \\
\hline 1247 & - & - & - & 1637 & $X$ & - & - \\
\hline 1257 & - & $\mathrm{X}$ & - & 1743 & - & - & - \\
\hline 1259 & - & - & - & 1765 & - & - & - \\
\hline 1298 & - & - & - & 1905 & - & $X$ & $\mathrm{X}$ \\
\hline 1373 & - & $\mathrm{X}$ & - & 1923 & - & - & - \\
\hline 1389 & - & $X$ & - & 1991 & - & $\mathrm{X}$ & - \\
\hline 1395 & - & - & - & 1999 & - & $\mathrm{X}$ & - \\
\hline 1461 & - & - & - & & & & \\
\hline
\end{tabular}

$\mathrm{CHCl}_{3}=$ chloroformic residue; $\mathrm{BuOH}=$ butanolic residue; $\mathrm{H}_{2} \mathrm{O}=$ aqueous residue; $\mathrm{H}=$ horizontal; $\mathrm{V}=$ vertical. $(-)$ = not antioxidant; $\mathrm{X}=$ antioxidant.

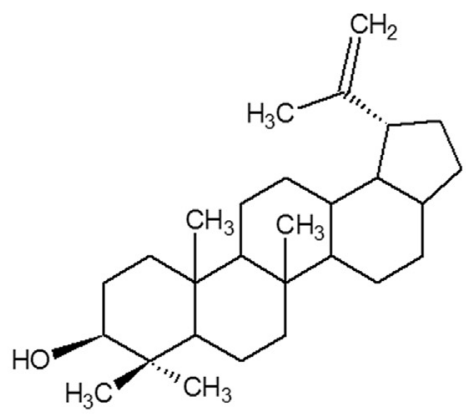

A

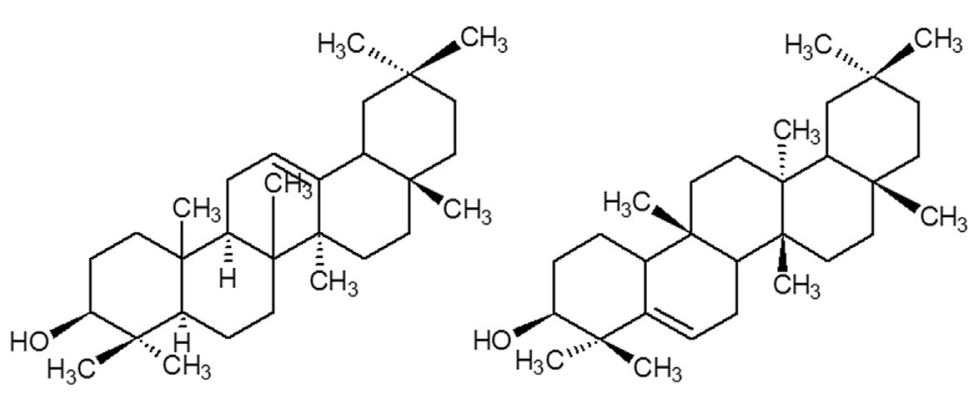

$\mathrm{B}$

C

Figure 3 - Molecular structure of UNIP-147 isolated compounds (A) lupeol, (B) $\beta$-amyrin and (C) 3 $\beta$-hydroxyglutin-5-ene.

E. faecalis: DDA and MDBA, understanding that both together might contribute to the prospection of new lead compounds in a complementary way. It is not the scope of the present manuscript to determine which assay is more suitable to be used - and discussions on the subject have widely been made before (Cowan, 1999). Briefly, natural products are complex mixture of substances that have different physical-chemical characteristics. Such differences may interfere with the characteristics of each DDA or MDBA assay due to the way chemicals can diffuse (in DDA) or dilute (in MDBA) in each type of medium. The use of both experiments seems to be complementary so far.

Based on analyses done with extracts in MDBA (Table 1) - which compared data from various concentrations of treatments tested against bacterial concentration of $1.0 \mathrm{x}$ $10 \mathrm{e} 5 \mathrm{CFU} / \mathrm{mL}$, it was possible to identify three promising extracts: EB 1493, EB 1637 and EB 1765. EB 1493 was ob- tained from aerial organs of Ipomoea alba $\mathrm{L}$. (Convolvulaceae). I. alba was barely studied in terms of its chemical constituents or pharmacological activity. The use of its latex was reported (Hosler et al., 1999). Sweet potato is one of the species belonging to Ipomoea genus. Clavine alkaloids occur in I. muricata (Maruia and Srivastava, 2009), as well as ipobscurines that are indol alkaloids from the macrolactam-type (Jenett-Siems et al., 2003) and alkaloids occur in some toxic species, as in I. carnea (Haraguchi et al., 2003). Other compounds as anthocyanins (Steed and Truong, 2008) and polyphenolic compounds (Kurata et al., 2007) also occur in Ipomoea species.

Extract 1637, obtained from Diclinanona calycina (Annonaceae), has shown a significant activity in the assay. Previous study made with $D$. calycina, tested against diverse microorganisms in an agar-diffusion model, has shown its activity against Streptococcus oralis and Myco- 
Table 3 - ${ }^{13} \mathrm{C}$ NMR (125 MHz, $\mathrm{CDCl}_{3}$ ) data for sample UNIP-147.

\begin{tabular}{|c|c|c|c|c|c|c|}
\hline \multirow[t]{2}{*}{ Carbon } & \multicolumn{6}{|c|}{$\delta(\mathrm{ppm})$} \\
\hline & $\begin{array}{c}\text { lupeol } \\
\text { (Mahato et al, 1994) }\end{array}$ & UNIP-147 & $\begin{array}{c}\beta \text {-amyrin } \\
\text { (Mahato et al, 1994) }\end{array}$ & UNIP-147 & $\begin{array}{l}\text { 3ß-hidroxiglutin-5-ene } \\
\text { (Gonzalez et al., 1987) }\end{array}$ & UNIP-147 \\
\hline 1 & 38.7 & 38.72 & 38.7 & 38.6 & 18.3 & 18.22 \\
\hline 2 & 27.4 & 27.46 & 27.3 & 27.38 & 27.93 & 27.98 \\
\hline 3 & 78.9 & 79.04 & 79 & 79.02 & 76.44 & 76.37 \\
\hline 4 & 38.8 & 38.93 & 38.8 & 38.86 & 40.90 & 40.84 \\
\hline 5 & 55.3 & 55.30 & 55.3 & 55.19 & 141.76 & 141.61 \\
\hline 6 & 18.3 & 18.32 & 18.5 & 18.42 & 122.10 & 122.05 \\
\hline 7 & 34.2 & 34.29 & 32.8 & 32.78 & 23.74 & 23.54 \\
\hline 8 & 40.8 & 40.80 & 38.8 & 38.96 & 47.55 & 47.24 \\
\hline 9 & 50.4 & 50.45 & 47.7 & 47.64 & 34.94 & 34.84 \\
\hline 10 & 37.1 & 37.17 & 37.6 & 37.84 & 49.83 & 49.69 \\
\hline 11 & 20.9 & 20.94 & 23.6 & 23.64 & 33.24 & 33.12 \\
\hline 12 & 25.1 & 25.15 & 121.8 & 121.74 & 30.45 & 30.36 \\
\hline 13 & 38 & 38.07 & 145.1 & 145.19 & 37.95 & 37.84 \\
\hline 14 & 42.8 & 42.84 & 41.8 & 41.72 & 39.40 & 39.30 \\
\hline 15 & 27.4 & 26.95 & 26.2 & 26.16 & 34.72 & 34.61 \\
\hline 16 & 35.5 & 35.59 & 27 & 27.19 & 35.19 & 35.25 \\
\hline 17 & 43 & 43.01 & 32.5 & 32.49 & 30.18 & 30.09 \\
\hline 18 & 48.2 & 48.32 & 47.4 & 47.43 & 43.21 & 43.07 \\
\hline 19 & 47.9 & 47.99 & 46.9 & 46.84 & 35.19 & 35.08 \\
\hline 20 & 150.9 & 150.96 & 31.1 & 31.09 & 28.32 & 28.14 \\
\hline 21 & 29.8 & 29.69 & 34.8 & 34.75 & 32.2 & 32.08 \\
\hline 22 & 40 & 40.01 & 37.2 & 37.29 & 30.05 & 29.85 \\
\hline 23 & 28.0 & 28.06 & 28.2 & 28.25 & 29.04 & 28.97 \\
\hline 24 & 15.4 & 15.39 & 15.5 & 15.55 & 25.51 & 25.45 \\
\hline 25 & 16.1 & 16.12 & 15.6 & 15.61 & 16.26 & 16.21 \\
\hline 26 & 15.9 & 15.94 & 16.9 & 16.82 & 18.47 & 18.39 \\
\hline 27 & 14.5 & 14.57 & 26 & 26.00 & 19.69 & 19.62 \\
\hline 28 & 18 & 18.01 & 28.4 & 28.41 & 32.46 & 32.41 \\
\hline 29 & 109.3 & 109.34 & 33.3 & 33.35 & 32.12 & 32.05 \\
\hline 30 & 19.3 & 19.31 & 23.7 & 23.71 & 34.6 & 34.53 \\
\hline
\end{tabular}

bacterium smegmatis (Carneiro et al., 2008). Annonaceae species were chemically studied before. Alkaloids (Pérez and Cassels, 2010) and acetogenins (McLaughlin, 2008) are the main classes of active compounds occurring in the family.

Extract EB 1765 was obtained from the flowers of Moronobea coccinea, a species belonging to Clusiaceae. Polycyclic polyprenylated acylphoroglucinols and oxidized derivatives (Marti et al., 2010) were isolated from $M$. coccinea, as well as xanthone derivatives and flavonoids (Mkounga et al., 2009).

DDA showed a different group of active extracts: EB 1257, EB 1493, EB 1525 and EB 1991. Extracts 1257 and 1991 were obtained from aerial organs of S. globulifera,
Clusiaceae in different periods of time. Chemistry of Ipomoea (EB 1493) species was previously discussed. Extract 1525 was obtained from the stem of Connarus ruber var. ruber (Connaraceae). It was observed that there is a lack of chemical data related to the genus Connarus. Extracts EB 1257 and EB 1991 were obtained from the same species, S. globulifera, Clusiaceae, but plants were collected in different periods of time. Reports relate biological activity maybe related to the presence of polycyclic polyprenylated acylphoroglucinols and oxidized derivatives (Marti et al., 2010). Xanthones are also present in the species (Pana et al., 2010). Chemical studies were performed with EB 1257 due to extract availability. So, isolation and identification of major compounds were performed and re- 
sulted in lupeol, $\alpha$-amyrin and $3 \beta$-hydroxyglutin-5-ene as isolated compounds, widely known for their biological and pharmacological activities.

All 25 extracts were submitted to an initial fractionation, resulting in three residues to each extracts: $\mathrm{CHCl}_{3}$, $\mathrm{BuOH}$ and $\mathrm{H}_{2} \mathrm{O}$. It was observed that after extracts 321 and 352 were fractionated, a significant improvement of the antibacterial activity could be observed in their $\mathrm{H}_{2} \mathrm{O}$ residue. For that reason, both extracts were also chosen to be studied in a near future. Extract 321, obtained from the leaves of Psidium densicomum (Myrtaceae), belongs to a group of plants (guajava family) well known to contain terpenes, triterpenoids and flavonoids (Ho et al., 2012; Gutierrez et al., 2008). Extract 352 was obtained from aerial parts of Stryphnodendron pulcherrimum (Fabaceae), species taxonomically related to a medicinal plant known in Brazil as barbatimao, that was already studied against oral pathogens (Pereira et al., 2011) to contain tannins as the main chemical class of compounds (Santos et al., 2002).

As fractionation of the 25 extracts was done exactly in the same way to obtain residues, added to the fact that all residues were tested at the same time, in both biological assays, it is possible to suggest a comparative analysis based on the results obtained from the biological assays of residues. Antibacterial results obtained from the residues when compared to their original extracts may take different courses: (a) biological activity has been missing during fractionation, and synergism was lost; (b) biological activity is concentrated in one fraction and its antibacterial activity may be improved or not, in relation to the original extract; (c) biological activity appears in two or more fractions and the antibacterial activity may have improved or not, in relation to the original extract. Based on that premises, a large number of extracts can be considered for further analyses, which is profitable but time-consuming. For that reason, it is primordial to establish a method according to which the extracts and their residues are going to be compared among each other, and the more adequate way is to rank MIC's and MBC's values of treatments when MDBA is used, and to compare growth inhibition zones of treatments by analysis of variance ANOVA, as applied in the present work when DDA is used. If that idea is applied, it is possible to create a ranking establishing which extract and/or residue is best to be prioritized in the studies.

As the current study aims the identification of a new compound to be used in root canal treatment, it is important to compare the efficacy of extracts treatments to $\mathrm{SH}$, which is one of the compounds of choice, for this application. SH was prepared at the concentration of $1 \%$ to be used as standard drug, despite its wide range of concentrations found in literature, ranging from 1 to $5.25 \%$ that are available in the marketing. Studies reporting the efficacy of SH in biofilms obtained from E. faecalis and/or S. mutans were done and this compound showed better efficacy when used against biofilms obtained from planktonic cultures (Jiang et al.,
2011). Although a direct comparison between SH and plant extracts is not feasible, since $\mathrm{SH}$ is an isolated compound and plant extracts are highly complex mixtures of compounds of various origins, the results obtained for $\mathrm{SH}$ provide an important reference for a comparative, albeit indirect, analysis of the antibacterial activity of extracts. Moreover, it is highly expected that when active substances are isolated from the extracts, they may become more active than the original extract, which is going to be further done.

Antioxidant activity was also evaluated, and resulted that 55. BuOH, 841. BuOH, 1257. BuOH, 1373. BuOH, 1389. $\mathrm{BuOH}, \quad 1525 . \mathrm{BuOH}, \quad 1525 . \mathrm{H}_{2} \mathrm{O}, \quad 1637 . \mathrm{CHCl}_{3}$, 1905.BuOH, 1905. $\mathrm{H}_{2} \mathrm{O}, 1991 . \mathrm{BuOH}, 1999 . \mathrm{BuOH}$ showed activity in the $\beta$-caroten TLC assay. Further evaluation of isolated compounds shall be done in the near future. Chemical data found in the literature is consistent with results we obtained in the TLC analysis of the main chemical classes as phenolic compounds, triterpenes and alkaloids, and will support future isolation procedures to be done with all seven active extracts.

Results related to the efficacy of the extracts against planktonic cultures do not assure that the extracts are going to be as effective against biofilms, and for that reason, further in vitro studies regarding the activity of extracts against biofilms are being developed today as well as the evaluation of the extracts in toxicological assays, in order to gather information to support in vivo studies (Barrella et al., 2012) with the extracts.

\section{Conclusions}

Nature is a potential source of new drugs to be used in Dentistry. In the present work, seven plant extracts obtained from species native to the Amazon rain forest showed significant activity against $E$. faecalis and showed that antioxidant compounds may be present as well, indicating that possibly phenolic compounds may be involved in antibacterial activity. Also, statistical design here proposed also contributes to optimize the decision-making of which extract shall be prioritized for chemical studies so as to isolate active compounds that might be introduced in endodontic therapy.

\section{Acknowledgments}

Authors thank FAPESP for their financial support

\section{References}

Alviano WS, Alviano DS, Diniz CG, Antoniolli AR, Alviano CS, Farias LM, Carvalho MA, Souza MM, Bolognese AM (2008) In vitro antioxidant potential of medicinal plant extracts and their activities against oral bacteria based on Brazilian folk medicine. Arch Oral Biol 53:545-552.

Aslangul E, Ruimy R, Chau F, Garry L, Andremont A, Fantin B (2005) Relationship between the level of acquired resistance 
to gentamicin and synergism with amoxicillin in Enterococcus faecalis. Antimicrob. Agents Chemother 49:4144-4148.

Barrella GE, Suffredini IB, Ribeiro FV, Cirano FR, Pimentel SP (2012) Evaluation of the effect of an organic extract obtained from Ipomoea alba L. on experimental periodontitis in rats. Braz Oral Res 26:158-164.

Carneiro AL, Teiceira MF, Oliveira VM, Fernandes OC, Cauper GS, Pohlit AM (2008) Screening of Amazonian plants from Adolpho Ducke forest reserve, Manaus, state of Amazonas, Brazil, for antimicrobial activity. Mem Inst Oswaldo Cruz 103:31-38.

Cowan MM (1999) Plant products as antimicrobial agents. Clin Microbiol Rev 12:564-582.

Duggan JM, Sedgley CM (2007) Biofilm formation of oral and endodontic Enterococcus faecalis. J Endod 33:815-818.

Estrela C, Silva JA, de Alencar AH, Leles CR, Decúrcio DL (2008) Efficacy of sodium hypochlorite and chlorhexidine against Enterococcus faecalis - A systematic review. J Appl Oral Sci 16:364-368.

Gutierrez RM, Mitchell S, Solis RV (2008) Psidium guajava: a review of its traditional uses, phytochemistry and pharmacology. J Ethnopharmacol 117:1-27.

Hancock HH $3^{\text {rd }}$, Sigurdsson A, Trope M, Moiseiwitsch J (2001) Bacteria isolated after unsuccessful endodontic treatment in a North American population. Oral Surg Oral Med Oral Pathol Oral Radiol and Endod 91:579-586.

Haraguchi M, Gorniak SL, Ikeda K, Minami Y, Kato A, Watson AA, Nash RJ, Molyneux RJ, Asano N (2003). Alkaloidal components in the poisonous plant, Ipomoea carnea (Convolvulaceae). J Agric Food Chem 51:4995-5000.

Ho R, Violette A, Cressend D, Raharivelomanana P, Corrupt PA, Hostettmann K (2012) Antioxidant potential and radicalscavenging effects of flavonoids from the leaves of Psidium cattleianum grown in French Polynesia. Nat Prod Res 26:274-277.

Hosler D, Burkett SL, Tarkanian MJ (1999) Prehistoric polymers: rubber processing in ancient Mesoamerica. Science 284:1988-1991.

Horner R, Liscano MG, Maraschin MM, Salla A, Meneghetti B, Dal Forno NLF, Righi RA (2005) Suscetibilidade antimicrobiana entre amostras de Enterococcus isoladas no Hospital Universitário de Santa Maria. J Bras Patol Med Lab 41391-41395.

Jenett-Siems K, Weigl R, Kaloga M, Schulz J, Eich E (2003) Ipobscurines $\mathrm{C}$ and $\mathrm{D}$ : macrolactam-type indole alkaloids from the seeds of Ipomoea obscura. Phytochemistry 62:1257-1263.

Jiang LM, Hoogenkamp MA, van der Sluis LWM, Wesselink PR, Crielaard W, Deng DM (2011) Resazurin metabolism assay for root canal disinfectant evaluation on dual-species biofilms. J Endod 37:31-35.

Kayaoglu G, Orstavik D (2004) Virulence factors of Enterococcus faecalis: relationship to endodontic disease. Crit Rev Oral Biol Med 15:308-320.

Kayaoglu G, Ömürlü H, Akca G, Gürel M, Gençay Ö, Sorkun K, Salih B (2011) Antibacterial activity of propolis vs. conventional endodontic disinfectants against Enterococcus faecalis in infected dentinal tubules J Endod 37:376-381.
Kristich AJ, Li YH, Cvitkovitch DG, Dunny GM (2004) Espindependent biofilm formation by Enterococcus faecalis. J Bacteriol 186:154-163.

Kurata R, Adachi M, Yamakawa O, Yoshimoto M (2007) Growth suppression of human cancer cells by polyphenolics from sweetpotato (Ipomoea batatas L.) leaves. J Agric Food Chem 55:185-190.

Love MR (2001) Enterococcus faecalis - a mechanism for its role in endodontic failure. Int Endod J 34:399-405.

Marti G, Eparvier V, Moretti C, Prado S, Grellier P, Hue N, Thoison O, Delpech B, Guéritte F, Litaudon M (2010) Antiplasmodial benzophenone derivatives from the root barks of Symphonia globulifera (Clusiaceae). Phytochemistry 71:964-974.

Maurya A, Srivastava SK (2009) Large-scale separation of clavine alkaloids from Ipomoea muricata by $\mathrm{pH}$-zonerefining centrifugal partition chromatography. $\mathrm{J}$ Chromatogr B Analyt Technol Biomed Life Sci 877:17321736.

McLaughlin JL (2008) Paw paw and cancer: annonaceous acetogenins from discovery to commercial products. J Nat Prod 71:1311-1321.

Mkounga P, Fomum ZT, Meyer M, Bodo B, Nkengfack AE (2009) Globulixanthone F, a new polyoxygenated xanthone with an isoprenoid group and two antimicrobial biflavonoids from the stem bark of Symphonia globulifera. Nat Prod Commun 4:803-808.

Pana E, Cao S, Brodie PJ, Miller JS, Rakotodrajaona R, Ratovoson F, Birkinshaw C, Andriantsiferana R, Rasamison VE, Kingston DG (2010) An antiproliferative xanthone of Symphonia pauciflora from Madagascar rainforest. Nat Prod Commun 5:751-754.

Pasticci MB, Mencacci A, Moretti A, Palladino N, Maria Lapalorcia L, Bistoni F, Baldelli F (2008) In vitro antimicrobial activity of ampicillin-ceftriaxone and ampicillin-ertapenem combinations against clinical isolates of Enterococcus faecalis with levels of aminoglycoside resistance. Open Microbiol J 2:79-84.

Pereira EM, Gomes RT, Freire NR, Aguiar EG, Brandão MG, Santos VR (2011) In vitro antimicrobial activity of Brazilian medicinal plant extracts against pathogenic microorganisms of interest in Dentistry. Planta Med 77:401-404.

Pérez EG, Cassels BK (2010) Alkaloids from the genus Duguetia. Alkaloids Chem Biol 68:83-156.

Pinheiro ET, Gomes BP, Ferraz CC, Sousa EL, Teixeira FB, Souza-Filho FJ (2003) Microorganisms from canals of root-filled teeth with periapical lesions. Int Endod J 36:1-11.

Pinheiro ET, Gomes BPFA, Drucker DB, Zaia AA, Ferraz CC, Souza-Filho FJ (2004) Antimicrobial susceptibility of Enterococcus faecalis isolated from canals of root filled teeth with periapical lesions. Int Endod J 37:756-763.

Pratt DE, Miller EE (1984) A flavonoid antioxidant in Spanish peanuts (Arachia hypogoea). JAOCS 61:1064-1067.

Santos SC, Costa WF, Ribeiro JP, Guimarães DO, Ferri PH, Ferreira HD, Seraphin JC (2002) Tannin composition of barbatimao species. Fitoterapia 73:292-299.

Souto R, Andrade AFB, Uzeda M, Colombo APV (2006) Prevalence of "non-oral" pathogenic bacteria in subgingival biofilm of subjects with chronic periodontitis. Braz J Microbiol 37:208-215. 
Steed LE, Truong VD (2008) Anthocyanin content, antioxidant activity, and selected physical properties of flowable purple-fleshed sweetpotato purees. J Food Sci 73:S215-S21.

Suffredini IB, Varella AD, Oliveira AA, Younes RN (2002) In vitro anti-HIV and antitumor evaluation of Amazonian plants belonging to the Apocynaceae family. Phytomedicine 9:175.

Suffredini IB, Sader HS, Gonçalves AG, Reis AO, Gales AC, Varella AD, Younes RN (2004) Screening of antibacterial active extracts obtained from plants native to Brazilian Amazon rain forest and Atlantic forest. Braz J Med Biol Res 37:379-384.

Suffredini IB, Paciencia MLB, Nepomuceno DC, Younes RN, Varella AD (2006) Antibacterial and cytotoxic activity of
Brazilian plant extracts Clusiaceae. Mem Inst Oswaldo Cruz 101:287-290.

Suffredini IB, Paciencia MLB, Varella AD, Younes RN (2006) Antibacterial activity of Brazilian Amazon plant extracts. Braz J Infect Dis 10:400-402.

Wagner H, Bladt S (1996) Plant Drug Analysis. A thin layer chromatography atlas. 2 ed. Springer, Berlin.

Younes RN, Varella AD, Suffredini IB (2007) Discovery of new antitumoral and antibacterial drugs from Brazilian plant extracts using high throughput screening. Clinics 62:763-768.

Younes RN, Varella AD, Suffredini IB (2000) Extração e rastreamento de novas drogas em plantas brasileiras. Acta Oncol Bras 20:15-19.

All the content of the journal, except where otherwise noted, is licensed under a Creative Commons License CC BY-NC. 